\title{
Molecular and morphological identification of fungal disease agent Trichothecium roseum developing secondarily to gray rot caused by Botrytis cinerea isolated from grapes in Turkey
}

Türkiye'de Botrytis cinerea ile enfekteli üzümlerde ikincil fungal hastalık etmeni Trichothecium roseum'un moleküler ve morofolojik olarak tanımlanması

\section{Fatih Mehmet TOK ${ }^{1}$}

${ }^{1}$ Hatay Mustafa Kemal University, Dept. of Plant Protection, Faculty of Agriculture, Hatay/Turkey.

\section{MAKALE BILGISI / ARTICLE INFO}

Makale tarihçesi / Article history:

DOI: $\underline{10.37908 / m k u t b d .978236}$

Geliş tarihi /Received:03.08.2021

Kabul tarihi/Accepted:17.09.2021

\section{Keywords:}

Trichothecium roseum, grapes, vine, mycotoxin, pink rot.

\footnotetext{
Corresponding author: Fatih Mehmet TOK

$\bowtie:$ ftok@mku.edu.tr
}

\section{Ö ZE T / A B S TR A C T}

Atıf / Citation: Tok FM (2021) Identification of Trichothecium roseum developing secondarily to gray rot caused by Botrytis cinerea isolated from grapes in Turkey. MKU. Tar. Bil. Derg. 26(3) : 720-725. DOI: 10.37908/mkutbd.978236

\section{INTRODUCTION}

Grapevine is one of the most economically important agricultural plant which is widely planted in Turkey with a total area under production over 400.000 hectares, producing over 4,2 million tons of grapes (FAO, 2020).
Hatay province of Turkey located east Mediterranean Region, bordered with Syria, has about $5 \%$ of grapevine growing areas of Turkey with about 48.000 hectares. Hassa district of Hatay province has $96 \%$ of the vineyard areas in this province. Turkey has an average vineyard area of approximately 450 thousand hectares and the 
Aegean Region comes first with the largest vineyard cultivation. Almost half of the country's vineyard areas are located in this region. Manisa province has the largest production area in this region and Denizli and Mersin are other major grape producing provinces in Turkey. Most of the early grape varieties are grown in Mersin, Adana and Antalya provinces. Aegean Region comes first in the production of table and dried grapes in Turkey and more than $50 \%$ of the country's production is met from this region. Manisa province alone meets $90 \%$ of Turkey's dried grape production (FAO, 2020; Semerci et al., 2015). Plenty of bacterial, viral and fungal disease agents cause diseases on leaves, stems, fruits and roots of vineyard plants and cause serious yield loss (Akgül, 2020). An intensive biological and chemical control program is implemented against these disease agents which can be find both in the vineyard areas and in the storages. Besides, there are fungi that are not economically damaging but produce mycotoxins in the vineyards. Mycotoxins are secondary metabolites produced by filamentous fungi and toxic to organisms. Although there are hundreds of mycotoxins produced by fungi in the nature, only a few of them are known to be associated with human health. Toxins declared by the Council of Agricultural Science and Technology (CAST) as hazardous to human health are aflatoxins, trichothecenes, fumonisins, zearalenone, OTA and ergot alkaloids. Others were considered less important, as there was no data to suggest that other toxins pose a health risk (CAST, 2013). The presence of mycotoxins in wine grapes not only poses a health risk, but also limits the shelf life and quality of wines.

Trichothecenes are very common toxins produced by Fusarium species and Trichothecium roseum. On the other hand, Serra et al. (2005) reported that the most important Trichothecenes producing fungus in wine grapes was $T$. roseum. The cellular structure of the fungus is ellipsoidal, filamentous; young conidia are aseptate but become septate as they mature. Colony of the fungus develops flat on the medium and is initially white, later pink in color, but can be observed pink to salmon in PDA medium. Conidiospores are ellipsoidal or pyriform in the form of the characteristic zigzag chain. $T$. roseum taxonomically belongs to the Ascomycota phylum, Sordariomycetes class and hypocreales order. The fungus is known as mycoparasite, saprophytic, weakness pathogen and opportunistic pathogen. It causes damage to melons, tomatoes, grapes and some other plants and fruits both in the field and in storages. However, it is an opportunistic pathogen in vineyards mostly observed together with Botrytis cinerea causal agent of gray mold (Oh et al., 2014).
During the summer of 2020, white and pale pink stains were observed on grape clusters in the field and on the harvested grapes in storages. These stains resembling powdery mildew on the grapes were observed on the clusters, mostly developing secondarily to gray rot caused by Botrytis cinerea. The disease symptoms occurred in both nationwide Yalova Incisi and Hatun Parmağı and in local varieties Pafı and Dökülgen. In previous studies, the white stains were reported as Acremonium sp, Trichothecium sp. (Park et al., 2004), Hanseniaspora sp. (Lee et al., 2005) and Trichothecium roseum was reported on grapes in South Korea by SohYoung et al. (2014).

In this study, we identified the causal disease agent of white and pale pink stains on grapes which were primarily infected by gray mold disease agent Botrytis cinerea in Turkey based on morphologic, pathogenic properties and internal transcribed spacer (ITS) sequence analysis.

\section{MATERIALS and METHODS}

\section{Isolation of fungus}

During the summer of 2020, white and pale pink stains were observed on grapes in the field and on the harvested grapes in storages. These stains were different from gray mold but observed associated with gray mold symptoms on grapes almost in all cases. To determine the causal agent of disease, some grape clusters were collected both from the 4 vineyards and the 3 storages located in Hassa district of Hatay province of Turkey. The different methods were used to isolate the fungus from the symptomatic tissues. Fruits showing disease symptoms were washed with sterile distilled water and $50 \mu \mathrm{L}$ of the wash water was spread on the potato dextrose agar (PDA) medium amended with streptomycin sulphate $(50 \mathrm{mg} / \mathrm{L})$. In the second method, a small piece of mycelial and conidial mass on the diseased grapes was transferred to Petri plates filled with PDA medium amended with streptomycin sulphate $(50 \mathrm{mg} / \mathrm{L})$ and incubated at $25^{\circ} \mathrm{C}$. After 7 days, colonies were transferred to PDA, V-8 juice agar and malt extract agar (MEA) medium and the single spore cultures were obtained as described earlier (Kurt et al., 2020). Petri dishes were incubated at $25 \circ \mathrm{C}$ for 20 days under a $12-\mathrm{h}$ light/dark photoperiod for morphological examination. After 20 days, morphological and colony characteristics of the fungus were examined.

\section{Morphologic identification}

Morphological identification was carried out by the methods reported by Sutton (1980). For this purpose, 
the isolated fungus was transferred to V-8 juice agar, malt extract agar, water agar and potato dextrose agar media and kept at 20, 25 and $30 \circ \mathrm{C}$ degrees for morphologic examination. Five petri dishes were used for each temperatures and incubated for 7 days under a 12-h light/dark photoperiod. After incubation period, colony size, colony color on the upper and reverse side of the Petri dishes. Mycelia of the fungus were examined under a binocular microscope and shape, size and position of the spores and fialides emerged from hypha were recorded. Additionally, hyphal characteristics were examined.

\section{Molecular identification}

To identify the fungus isolated from the symptomatic grapes, mycelial plugs were transferred to PDA medium amended with streptomycin sulphate. After 10 days of incubation at $25 \circ \mathrm{C}$, mycelia were collected directly from the Petri dishes with a spatula. Around $200 \mathrm{mg}$ of wet mycelia were used for DNA extraction. Total DNA was extracted by using Quick-DNA ${ }^{\text {TM }}$ Fungal/Bacterial Miniprep Kit (Zymo Research, USA). After extraction, DNA concentration was measured by nano drop and kept at -20 until use.

For molecular identification, ITS rDNA gene sequence was amplified using ITS1 (5'-CGTAGGTGAACCTGCGG-3') and ITS4 (5'-TCCTCCGCTTATTGATATGC-3') primers (Staats et al., 2005). Polymerase chain reaction (PCR) analysis was performed according to the method suggested by Staats et al. (2005). PCR conditions were as follow; after initial denaturation at $94^{\circ} \mathrm{C}$ for 2 mins, 94ㅇ $\mathrm{C}$ for $40 \mathrm{sec}$. denaturation, $60^{\circ} \mathrm{C}$ for $1 \mathrm{~min}$ annealing and then $72^{\circ} \mathrm{C}$ for $1 \mathrm{~min}$ extension over 30 cycles. And final condition was $72^{\circ} \mathrm{C}$ for 5 minutes. PCR product was run into $1 \%$ agarose gel electrophoresis and then sent to a private company for sequencing.

\section{Pathogenicity test}

Grape berries, petioles, stems, axillary buds and clusters were collected from Yalova Incisi grape variety, which is very common in Hassa district of Hatay province, and transferred to the laboratory in an icebox. All organs were surface disinfested with $1 \%$ sodium hypochlorite solution, washed with sterile distilled water and kept in room temperature to dry. In order to prepare spore suspension, the fungus was grown on PDA medium at $25^{\circ} \mathrm{C}$ for 10 days. After 10 days, sterile distilled water poured into Petri dishes and mycelia and spores of the fungus were scratched with a sterile spatula. The suspension was then filtered through 4 layer of cheese cloth and spore concentration was adjusted to $2 \times 106$ conidia/mL by using a haemocytometer. Spore suspension was sprayed onto grape berries, petioles, stems, axillary buds, clusters and some plant organs on which sprayed only sterile distilled water were kept as control. Inoculated and un-inoculated plant organs were transferred to crysperboxes and incubated at $25^{\circ} \mathrm{C}$ for two weeks.

\section{RESULTS and DISCUSSION}

\section{Isolation and morphologic identification of the fungus}

During summer of 2020, a fungus was consistently isolated during the surveys conducted to identify the causal agent of the diseases symptoms observed in Hassa district of Hatay Province of Turkey. White to pale pink colored stains were observed on the grapes Yalova Incisi, Antep Karası, Hatun Parmağı, Pafı and Dökülgen varieties. All the varieties seemed susceptible to disease. These white to pale pink stains were mixed with gray mold symptoms and seemed secondarily to gray mold disease caused by Botrytis cinerea. The mean disease prevalence was $10 \%$ and disease incidence was $15 \%$. The first isolation technique resulted mixed fungus colonies with pinkish colonies and Botrytis sp. In the second isolation technique, after transferred pink stains to PDA medium, mostly pure white to pink colonies were observed. After 5-6 days, the fungus produced septate mycelia abundantly which seemed white in the beginning then turned into pale pink and salmon color gradually (Figure 1-A, B). Conidiophores were long $(150 \sim 260 \mu \mathrm{m})$, septate, slender and conidia were produced apically attached singly and in groups or chains (Figure 1-C). Conidia were mostly hyaline, ovoid and 2celled, $18^{\sim} 22 \times 8 \sim 10 \mu \mathrm{m}$ in size, of ovoid or ellipsoid shape, and characteristically held together in zigzag chains (Fugure 1-D). Based on the characteristics, the fungus was identified as Trichothecium sp. (Howard et al., 1994). 


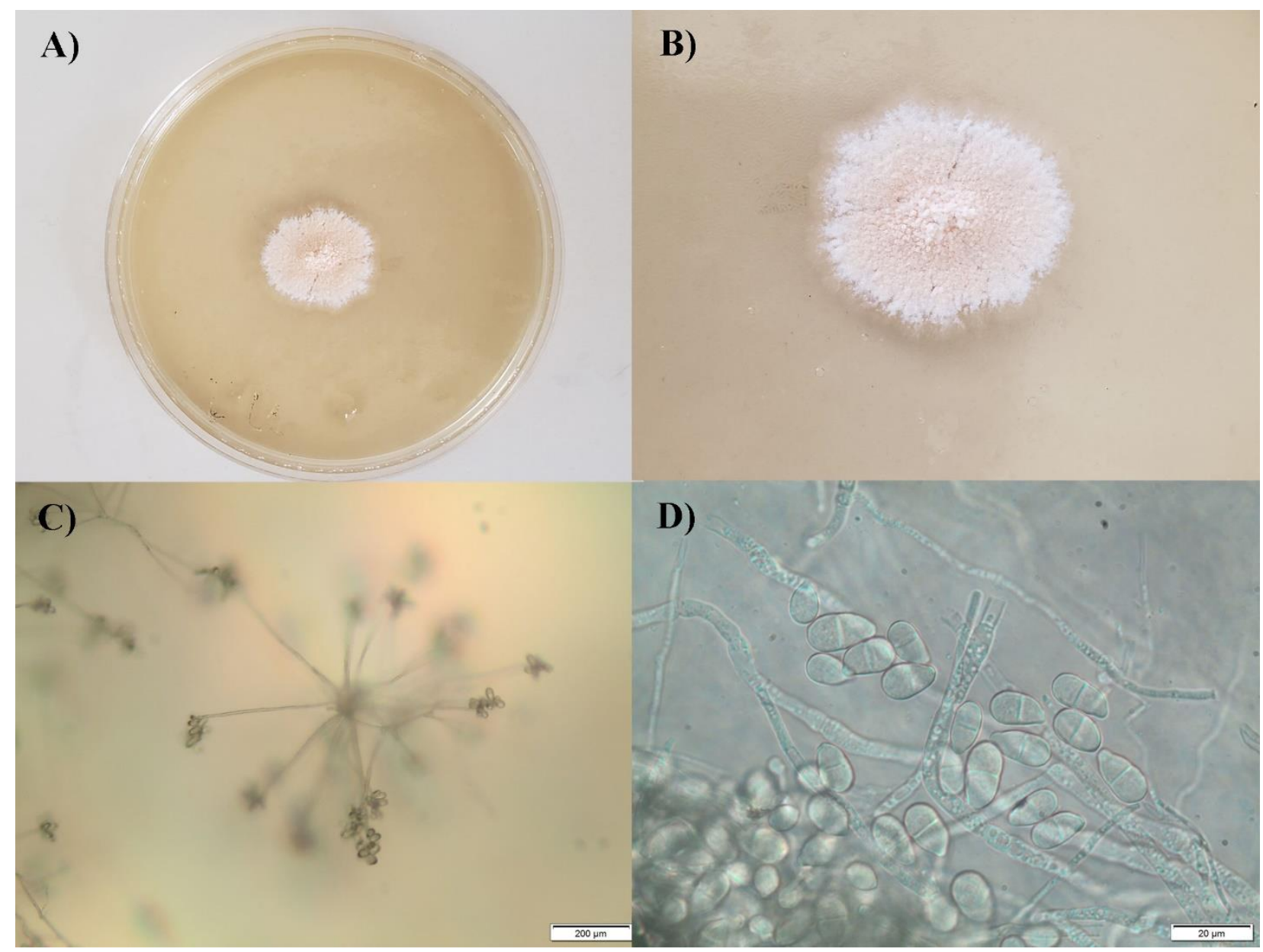

Figure 1. A and B: Colony morphology of T. roseum on PDA medium. C: Conidiophores and apical spores. D: spores.

\section{Molecular identification}

The PCR products run in $1 \%$ agarose gel produced approximately $700 \mathrm{bp}$ bands. The ITS sequence of isolate (GenBank accession Num. MZ407606) indicated 99\% similarity with Trichothecium roseum (GenBank Num. KP982888.1). Therefore, the causal disease agent isolated from grapes was identified as $T$. roseum based on molecular data.

\section{Pathogenicity test}

After 2 weeks of incubation, diseases symptoms observed resembling those in the field on the inoculated plant organs. White to pinky mycelial growth was observed on the grape fruits, petioles, stems, axillary buds and clusters (Figure 2-A, B, C, D). Fruits and stem of the vine seemed more resistant to the fungus because every berry stabbed with a needle had disease symptoms but others. Microscopic observations on the inoculated plant organs showed the same morphological features with $T$. roseum and the fungus re-isolated from all inoculated plants. 

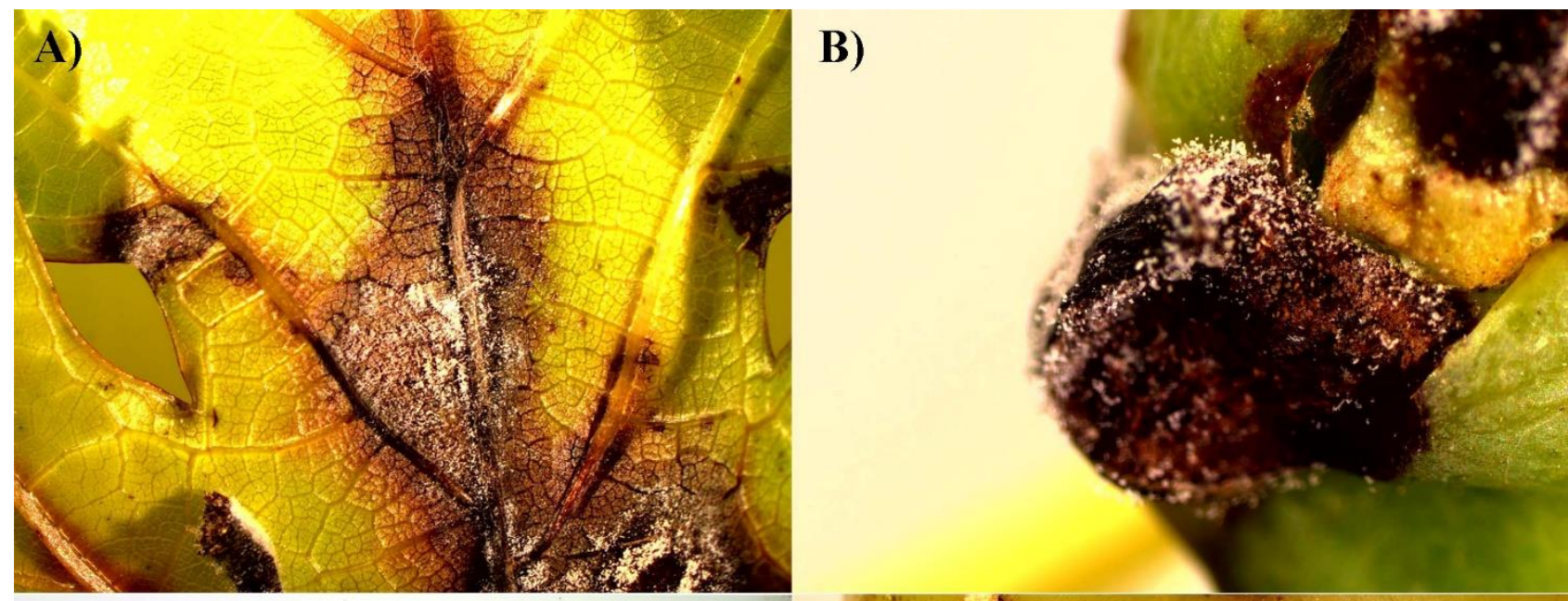

C)
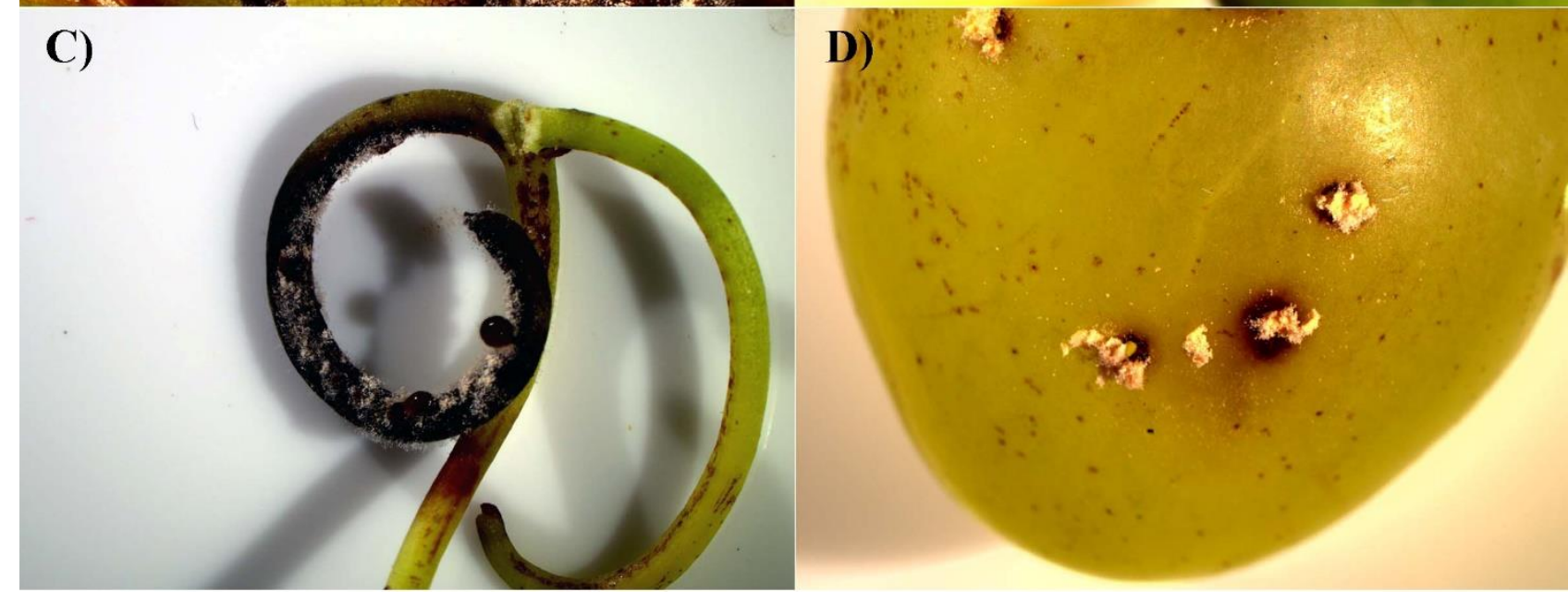

Figure 2. Symptoms of Trichothecium roseum infections on different grapevine organs A: on leaf, B: on axillary bud, C: on cluster and D: on fruit.

$T$. roseum is observed in many countries worldwide and can grow in a variety of habitats ranging from leaf litter to fruit crops (Onions et al., 1981). The fungus produces a wide variety of secondary metabolites including mycotoxins, such as roseotoxins and trichothecenes, which can contaminate and spoil a variety of fruit crops and reduces the wine quality especially in red wines (Batt et al., 2014). It can act as both a secondary and opportunistic pathogen by causing pink rot on many fruits and vegetables and generally cause light to moderate disease severity. In our study, the fungus was present on grapes which mostly infected with B. cinerea. On the fruits of grape, $T$. roseum grown on the fruit skin and cannot proceed to the inner tissues. But because of mycotoxins produced by the fungus it has an economical and health impacts on the farming industry. In previous studies, $T$. roseum was reported on Tomato in Argentina (Dal Bello, 2008) and in South Korea (Han et al., 2012), on grapes in South Korea (Oh et al., 2014), on Chinese Peach (Prunus davidiana) in China (Li et al., 2020), on peach and muskmelon in Japan (Takahashi et al., 1995).
In our study, $T$. roseum infecting grapes was detected and identified first time in Turkey.

In conclusion, $T$. roseum infecting grapes was detected and identified first time in Turkey by this study. $T$. roseum is both a secondary and opportunistic pathogen by causing pink rot on many fruits and vegetables and generally cause light to moderate disease severity. In our study, the fungus was present on grapes which mostly infected with B. cinerea. On the fruits of grape, T. roseum grown on the fruit skin and cannot proceed to the inner tissues. But because of mycotoxins produced by the fungus it has an economical and health impacts on the farming industry. Since it causes health problems by producing mycotoxins, this fungus should be observed closely and studies on its control techniques should be carried out by the future experiments.

\section{ÖZET}

Amaç: Türkiye'de bağ alanlarında Trichothecium roseum'un ilk kez teşhis edilmesi.

Yöntem ve Bulgular: 2020 yaz ayları boyunca, hem 
bahçede hem de hasat edilen üzümler üzerinde beyazdan açık pembe renge kadar değişen renklenmeler gözlemlenmiştir. Üzümler üzerinde külleme belirtilerini andıran bu lekelenmelerin genellikle Botrytis cinerea'nın neden olduğu kurşuni küfle birlikte bulunduğu tespit edilmiştir. Hastalığın nedenini tespit etmek amacıyla Hassa ilçesine bağlı üzüm yetiştirilen alanlardan hastalıklı asma bitkilerine ait organlar toplanarak laboratuvara getirilmiştir. İzolasyonda iki farklı yöntem kullanılmış ve ayrıca ITS rDNA gene bölgeleri ITS1 ve ITS4 primer çifti ile çoğaltılarak sekans analizi yapılmıştır. Spor süspansiyonu yaprak, meyve, sürgün gibi bağ organlarına püskürtülerek patojenisite gerçekleştirilmiştir. Patojenisite testinden 7 gün sonra oluşan belirtiler bahçe şartlarında oluşanlarla aynı olduğu gözlemlenmiştir. ITS1/4 çifti ile çoğaltılan gen bölgesinden 700 bazlık bir dizi üretilmiş ve blast analizi gerçekleştirilerek Trichothecium roseum izolatına \%99 oranında benzer bulunmuştur. Morfolojik ve moleküler özelliklerine göre, elde edilen fungus Trichothecium roseum olarak teşhis edilmiş ve bu fungus Türkiye'de bağlar üzerinde ilk kez bu çalışma ile tespit edilmiştir.

Genel Yorum: Türkiye'de bağ alanlarında Trichothecium roseum bulunmakta ve Hassa ilçesine ait yetiştiricilik alanlarındaki Trichothecium roseum' un yoğunluğu ya da yaygınlı̆̆ bakımından bir farklılık bulunmamaktadır.

Çalışmanın Önemi ve Etkisi: Trichothecium roseum Türkiye'de bağlar üzerinde ilk kez bu çalışma ile tespit edilmiştir. Bu fungus ekonomik olarak önemli kayıplar meydana getirmemekte ancak ürettiği mikotoksinler sebebiyle hem ekonomik hem de sağlık sorunlarına yol açmaktadır.

Anahtar Kelimeler: Trichothecium roseum, üzüm, bağ, mikotoksin, pembe çürüklük.

\section{REFERENCES}

Akgül DS (2020) Asmalarda fungal gövde hastalıklarının araştırılmasında farklı inokulasyon yöntemlerinin karşılaştırılması. MKU Tar. Bil. Derg. 25(2): 262-270.

Batt CA, Tortorello M (2014) Encyclopedia of food microbiology (2 ed.). London: Elsevier Ltd. p. 1014. ISBN 978-0-12-384730-0.

CAST (2013) Council for agricultural science and technology, Mycotoxins, risks in plants, animal and human systems, Report No. 139, CAST,Ames, 2003.

Dal Bello G (2008) First report of Trichothecium roseum causing postharvest fruit rot of tomato in Argentina. Australasian Plant Disease Notes 3: 103-104.

FAO (2020) Food and Agriculture Organization of the United Nations, Rome, Italy Web. http://
www.fao.org/faostat/en/\#data/QC.

Han KS, Lee SC, Lee JS and Soh JW (2012) First report of pink mold rot on tomato fruit caused by Trichothecium roseum in Korea. Res. Plant Dis. 18(4): 396-398.

Kurt Ş, Soylu S, Uysal A, Soylu EM, Kara M (2020) Ceviz gövde kanseri hastalığı etmeni Botryosphaeria dothidea'nın tanılanması ve bazı fungisitlerin hastalık etmenine karşı in vitro antifungal etkinliklerininin belirlenmesi. MKU Tar. Bil. Derg. 25: 46-56.

Lee Y, Kim GG, Chung YR (2005) Identification of Hanseniaspora (Kloeckera) sp. related with white dusty symptom of the grape. Res. Plant Dis. 11: 198200.

Li YB, Zhang ZP, Luo LX, Li JQ and Hao JJ (2020) First report of Trichothecium roseum causing pink fruit rot of Prunus davidiana in China. Plant Dis. 104(9): 2520.

Oh SY, Nam KW and Yoon DH (2014) Identification of Acremonium acutatum and Trichothecium roseum isolated from grape with white stain symptom in Korea. Mycobiology 42(3): 269-273.

Onions AHS, Allsopp D, Eggins HOW (1981). Smith's Introduction to Industrial Mycology (7th ed.). London, UK: Arnold. ISBN 978-0-7131-2811-6.

Park JH, Han KS, Lee JS, Jang HI, Yiem MS (2004) Causal reason and control measures of 'Campbell Early' grape. Korean J. Hortic. Sci. Technol. 22: 84.

Semerci A, Kızıltuğ T, Çelik AD, Kiracı MA (2015) Türkiye bağcılığının genel durumu. Mustafa Kemal Üniversitesi Ziraat Fakültesi Dergisi 20(2): 42-51.

Serra R, Braga A, Venancio A (2005) Mycotoxinproducing and other fungi isolated from grapesfor wine production, with particular emphasis on ochratoxin A. Research in Microbiology 156: 515-521.

Staats M, Van Baarlen P, Van Kan JA (2005) Molecular phylogeny of the plant pathogenic genus Botrytis and evolution of host specificity. Mol. Biol. Evol. 22: 33346.

Sutton B C (1980) The Coelomycetes. Fungi with pycnidia, acervuli and stromata. Commonwealth Mycological Institute, Kew, Surrey, United Kingdom.

Takahashi H, Uematsu S, Oizumi T, Mori E, Yanagihori S, Ichinoe M (1995) Pink mold rot of muskmelon and tomato fruits and trichothecin production by Trichothecium roseum. Mycotoxins 41: 53-59. 